\title{
Factors Education Towards the Presentation of Accounting Information
}

\author{
Sri Dewi Anggadini \\ Universitas Komputer Indonesia \\ Bandung, Indonesia \\ sri.dewi@email.unikom.ac.id
}

\begin{abstract}
This study aimed to identify and analyze the factors of education that affect the presentation of accounting information. The case study was conducted in Pharmaceutical wholesaler company (PBF) in Bandung City Indonesia. The method used in the research was a quantitative method by performing a linear regression analysis. The retrieval of data was obtained from 31 branch offices of PBF. Validity test was performed by Spearman Rank test and reliability was calculated by Cronbach Alpha formula. The results Showed that the factors of education positively and Significantly Affect on the presentation of accounting information partially. Quality of education has a significant effect on the presentation of accounting information. The research contributed to provide recommendation led to more qualified accounting information.
\end{abstract}

Keywords - education, accounting information, presentation

\section{INTRODUCTION}

Human resource (HR) is a major asset of an organization roomates Became active planners and perpetrators of any activity of the organization[1]. Qualified human resources could not be separated from the educational factor. Education is an important thing that greatly Affects a person's development. Education is Believed to instil the knowledge, skills, and values by the which one can improve his ability. Education is a catalyst in the development of human resources [2]. Education is a fundamental component of human resource development Efforts. Qualified human resources of the which has the competitive advantage, all of it can only be acquired through education. Improving human resources can be done through formal education. The higher education that has been taken, both formal and non-formal education in accordance related to the field work, the higher one owns intellectual experience. The more educated workers Also are demanding more involvement in corporate decision making [3]. The ability of education and experience will Obtained finished increase of satisfaction in the accounting information and will continue to use it to help finish the job Because It has sufficient knowledge and skills [4]. The point here is with education and experience (the accounting department employees) will greatly assist in implementing activities in the company. In this study a formal education is the education that is owned by the accounting department staff Because the relevant level of education will Affect the job done [5]. Accounting department staff that has a level of education that is relevant to the work he does will have much more knowledge and information so that the skills Possessed will be reflected on the results of work performed.

The prior research that indicated resources were key issues of accounting information quality were human and system issues, organizational structure, etc. However this research did not explain in detail about the education factor [3]. Also Described about accounting information quality[6]. Unfortunately, the research did not explained about how education can influence factors on its presentation of accounting information [2].

That information is useful and processed so that it could be used as a basis for making the right decisions[7]. Information is a set of the data that has been processed into something that has broad meanings and uses. Information can be defined as the result of processing the data in a form that is more useful and more meaningful to the recipient who describes an event - a real event that is used for decision making. Based on the above understanding, it can be synthesized that the information is the data that has been processed through the process to make it more useful for the recipient so that it can assist in decision making.

Accounting is an information system of the which means that accounting is produced from an integrated process, such as identification, recording and communicating economic information[8]. American Accounting Assessment (AAA) the notion of accounting is the process of identifying, measuring, and reporting economic information to allow for a clear and firm assessments and decisions for Reviews those who use the information.Meanwhile, that the notion of accounting is a discipline Provides important that information so as to enable the implementation and evaluation of the company's path efficiently. Accounting is the process of identifying, recording and processing of data relevant in order to produce information to makedecisions[9].

This study purposed to identify and analyze the factors of education that Affect the presentation of accounting information. Linear Regression Analysis was used in the research as the research method. The retrieval of data was Obtained from 31 branch office of PBF. Validity test was performed by Spearman Rank test and reliability was calculated by Cronbach Alpha formula.

\section{METHOD}

Object of this study consisted of education ( $\mathrm{X}$ the presentation of accounting information (Y). This study uses census with the explanatory type of research is a case study, to clarify the relationship between the variables used in this study by testing the hypothesis - testing research that has been set. While the techniques used are cross-sectional. the target population in this study were all PBF Headquarters Bandung the which amounts to 31 companies. This research was conducted on March 1 - August 1, 2017 in the city of Bandung Indonesia 
Measurement of the variables used in this peneitian conducted through questionnaires and scoring through ordinal measurements using regression analysis through the Method of Successive Interval (MSI).

As to see the relevance of education and presentation of financial statements in the areas of finance staff, then used the method uses the assumption that $\mathrm{H} 0$ hypothesis. $\beta 1 \leq 0$ and H1. $\beta 1>0>0$.

\section{RESULTS}

Based on Figure 1 shows that the educational factor influenced the presentation of accounting information in this case is the financial statements. The financial statements are presented properly that will certainly occur Because The education that is owned by the finance department is Appropriate and relevant.

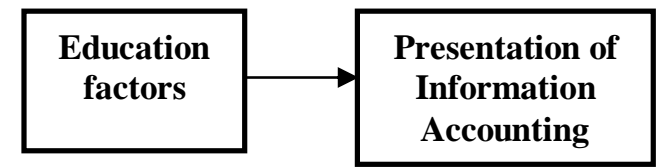

Fig.1. Research paradigm

$\mathrm{H} 1$ :There is a positive influence on educational factors on the presentation of accounting information.

Verification analysis is used to test the conceptual hypothesis based on the results of statistical calculations. The conceptual hypothesis proposed is the influence of the presentation of the accounting information system on internal control and its impact on employee performance. The statisticalthe method used is linear regression analysis (Linear Regression Analysis).In structural equation modeling there are two types of models that are formed items, namely the measurement models (outer model) and the structural models (inner model). The measurement models Explains the variance proportions of each manifest variable (indicator) can be explained in the which latent variables. Through the measurement models, it will be known the which indicators are domains in the formation of latent variables. After the measurement models of each latent variable is Described, then the structural models is Described the which will examine the effect of each latent exogenous variables on the endogenous latent variable.In this study there are two latent variables items, namely the presentation of accounting information and educational factors. The following models will be presented in the research.

\section{DISCUSSION}

Description of the collected of data that the accounting staff of PT PBF Bandung has an accounting education background of $13.64 \%$, with an accounting - management background and another of $81.82 \% \quad 4: 45 \%$ having an accounting, management and legal education background above explanation illustrates. The that the educational background of accounting staff is accounting. Then the results of this study illustrate that the educational background of the accounting department staff is Accounting -
Management, seen by the large number of respondents choosing an accounting - answer management education that is equal to $81.28 \%$. Judging from the factors of education of staff accounting for the accounting department at PT PBF Bandung City Consist of Formal education level, in education and Commulative Competency Achievement Index (GPA),

Presentation of information accounting consists of the fair presentation of financial statements, presentation characteristics, the disclosures of transaction balances between related parties with parties that have no related relationships, characteristics of presentation of income statements, presentation of notes to financial statements, disclosure of accounting changes, and statements on notes to financial statements. Judging from the variable presentation of accounting information at PT PBF Bandung City, it turns out that the weight of the respondents' scores included in the good category. The Recapitulation and picture above PROVE that the presentation of accounting information has been Carried out in accordance with the applicable procedures [7].

Whether or not to see the influence of educational factors on the presentation of accounting information at PT PBF Bandung, the hypothesis will be tested statistically as follows:

H0. $\beta 1 \leq 0$ : There is no positive influence on educational factors on the presentation of accounting information

H1. $\beta 1>0>0$ : There is a positive influence on educational factors on the presentation of accounting information

The calculation results Obtained by the value of t-count for educational factors by 2652 and from table t-student with $\alpha=0: 05$ and degrees of freedom $(\mathrm{db})=17$ for a one-sided $\mathrm{t}$ table testing Obtained value $=1.740$. With the testing criteria of one right-hand side (positive) is "Reject Ho if $t$ count $>t-$ table" , Because the t-count value for the coefficient of education variables factor is greater than t-table, the which is the $\mathrm{t}$-count $=2,652>\mathrm{t}$ table $=1,740$ then at the significance level of 5\% Ho is rejected and H1 is accepted. So it can be concluded that with a $95 \%$ confidence level there is a significant positive influence from the education factor on the presentation of accounting information presentation at PT PBF Bandung. The level of education has a positive effect on the presentation of accounting information presented. The higher the education of a person, the more knowledge and skills that people have, so that it will have an impact on the presentation of accounting information[10]. With the higher education section accounting staff, the better it will be in presenting accounting information, education is related to an Increase in knowledge and understanding of the environment as a whole [11]. So that it will make it Easier for someone to do work.An educated person will have competitiveness advantages. Education is a fundamental component of human resource development[2]. Quality human resources have a competitive advantage, they can only be Obtained through education [12]. 
The results of this study support the hypothesis that has been proposed that the education partially (individual) Significantly Affect and positively to the presentation of accounting information on the Company Wholesalers (PBF) Bandung City Center, The higher the level of education of a person, the more accounting information will be presented.

\section{ACKNOWLEDGMENT}

Thank you for the support from the Rector who has facilitated the issuance of this proceeding.

\section{REFERENCES}

[1] Jackson, Susan E., Randall S. Schuler, and Steve Werner. "Managing human resources," Mason, OH: South-Western Cengage Learning, 2009.

[2] Abdul Djalil Indris Saputra. "Humans build Indonesia, Proceedings of the Symposium on Culture Indonesia-Malaysia Eighth (SKIM 8), UKM Bangi, 2002.

[3] Goldin, Claudia, and Lawrence F. Katz. "The race between education and technology." Inequality in the 21 st Century. Routledge, , pp 49-54, 2018.

[4] Feingold, Carol E., "Margaret Calaluce, and Michael A. Kallen. "Computerized patient models and simulated clinical experiences:
Evaluation with baccalaureate nursing students." Journal of Nursing Education 43.4, Pp156-163, 2004.

[5] Ingersoll, Richard M. "The teacher shortage: A case of wrong diagnosis and wrong prescription." NASSP bulletin 86 631. Pp 16-31, 2002 .

[6] Choe, Jong-min. "The relationships among management accounting information, organizational learning and production performance." The Journal of Strategic Information Systems 13.1. 61-85, 2004

[7] Larrinaga-González, Carlos, et al. "The role of environmental accounting in organizational change-An exploration of Spanish companies." Accounting, Auditing \& Accountability Journal, 213-239 14.2, 2001.

[8] Pang Bo, Lillian Lee, and Shivakumar Vaithyanathan. "Thumbs up ?: sentiment classification using machine learning techniques." Proceedings of the ACL-02 conference on Empirical methods in natural language processing-Volume 10. The Association for Computational Linguistics, 2002.

[9] Hall, James A. “Accounting information systems," Cengage Learning, 2012

[10] Selim, Hassan M. "Critical success factors for e-learning acceptance: Confirmatory factor models." Computers \& Education, 396-413 49.2, 2007.

[11] Watts, Ross L. "conservatism in accounting part I: Explanations and implications." Accounting horizons 207-221, 17.3, 2003.

[12] Mohamed Ehab KA, and Sherif H. Lashine. "Accounting knowledge and skills and the challenges of a global business environment." Managerial Finance 29.7. 3-16, 2003. 